\title{
Turkish Version of Evaluation of Ankylosing Spondylitis Quality of Life Questionnaire in Patients With Ankylosing Spondylitis: A Validation and Reliability Study
}

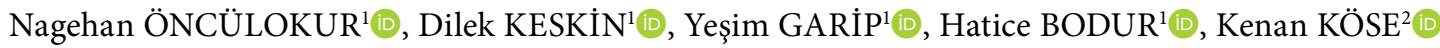 \\ ${ }^{1}$ Department of Physical Medicine and Rehabilitation, University of Health Sciences, Ankara Numune Training and Research Hospital, Ankara, Turkey \\ ${ }^{2}$ Department of Biostatistics, Medicine Faculty of Ankara University, Ankara, Turkey
}

\begin{abstract}
Objectives: This study aims to translate the Evaluation of Ankylosing Spondylitis Quality of Life (EASi-QoL) into the Turkish language and test its validity and reliability.

Patients and methods: A total of 100 AS patients (74 males; 26 females; mean age $38.2 \pm 9.9$ years; range 21 to 63 years) were included. The mean disease duration was 115.9 \pm 91.6 months. EASi-QoL was translated from English into Turkish, and synthesis, back translation, revision, and pretest stages were performed. All patients were asked to complete the Turkish version of EASi-QoL. The internal consistency of EASi-QoL was determined with Cronbach's alpha coefficient, and test-retest reliability was assessed by calculating the intra-class correlation coefficient. Confirmatory and explanatory factor analyses were performed to assess structural validity. Construct validity was also investigated by comparing the results of EASi-QoL with the Bath Ankylosing Spondylitis Disease Activity Index (BASDAI), Bath Ankylosing Spondylitis Functional Index (BASFI), Bath Ankylosing Spondylitis Metrology Index (BASMI), Ankylosing Spondylitis Disease Activity Score, Maastricht Ankylosing Spondylitis Enthesitis Score (MASES), and AS-specific QoL scale.

Results: Cronbach's alpha coefficient was 0.910 in the physical function category, 0.893 in the disease activity category, 0.935 in the emotional wellbeing category, and 0.930 in the social contribution category ( $a>0.7$ ). Factor loadings of all items in EASi-QoL were higher than 0.7 , indicating the high reliability of the questionnaire. There was also a strong positive correlation between all subcategories of EASi-QoL (physical function, disease activity, emotional well-being and social participation) and AS-specific QoL scale, BASDAI, Bath BASFI, patient's global assessment and pain severity. MASES and BASMI showed a moderate correlation with emotional well-being and social participation categories of EASi-QoL.

Conclusion: Turkish version of EASi-QoL is a reliable and valid scale that can be used in clinical practice to evaluate QoL in detail in patients with AS. Keywords: Ankylosing spondylitis; EASi-QoL; quality of life.
\end{abstract}

Ankylosing spondylitis (AS) is a chronic systemic inflammatory disease that belongs to spondyloarthritis group. It causes pain, stiffness and affects sacroiliac joints at early stages and axial skeleton at later stages. ${ }^{1}$ It is a complex and debilitating disease with a worldwide prevalence ranging up to $0.9 \% .^{2}$ Pain, fatigue, stiffness, disability, and extraarticular manifestations associated with AS cause diminished quality of life (QoL). ${ }^{3}$
Scales used in assessing AS patients focus particularly on the patient's symptoms or functional deficits. These scales include the Bath Ankylosing Spondylitis Functional Index (BASFI), Dougados Functional Index, modified Health Assessment Questionnaire for Spondyloarthropathies, and modified AS Arthritis Impact Measurement Scales 2. All of these scales provide valuable information regarding the impact of the disease on the patient and the functional status. However,

\section{Received: August 11, 2017 Accepted: January 24, 2018 Published online: April 11, 2018}

Correspondence: Nagehan Öncülokur, MD. Department of Physical Medicine and Rehabilitation, Numune Training and Research Hospital, 06230 Altındağ, Ankara, Turkey. Tel: +90 312 - 5084813 e-mail: nagehanonculokur@gmail.com

\section{Citation:}

Öncülokur N, Keskin D, Garip Y, Bodur H, Köse K. Turkish version of evaluation of ankylosing spondylitis quality of life questionnaire in patients with ankylosing spondylitis: A validation and reliability study. Arch Rheumatol 2018;33(4):443-454. 
they do not provide sufficient information about the QoL. ${ }^{4}$

Quality of life is defined as "an individual's perception of their position in life in the context of the culture and value systems in which they live and in relation to their goals, expectations, standards, and concerns" by the World Health Organization (WHO). ${ }^{5}$ Health-related quality of life (HRQoL) is a component of QoL which is mainly affected by health condition and clinical interventions. ${ }^{6}$ QoL commonly includes symptoms, functional status, work ability, social contact, emotional functions, treatment adverse effects, and financial costs. ${ }^{7}$ HRQoL scales are increasingly being used as outcome measures to evaluate the impact of diseases and health outcomes in routine follow-up and clinical studies. These scales enable the assessment and the treatment to focus on the patient rather than the disease. ${ }^{8}$

There is a growing interest in the development of disease-specific HRQoL scales designed to be associated with specific health problems. AS-specific QoL scales include Ankylosing Spondylitis Quality of Life (ASQoL) and Patient Generated Index-AS (PGI-AS). Studies have shown that PGI-AS, which was developed to assess a patient's life expectancies and the impact of disease on these expectancies, is correlated with the ASQoL, the Bath Ankylosing Spondylitis Disease Activity Index (BASDAI), and The European Group for Health Measurement and QoL Assessment. ${ }^{4,9}$ ASQoL is also a valuable tool for assessing the impact of AS on QoL from the patient's perspective. ${ }^{4}$

Although QoL is an important outcome measure in the evaluation of AS, the Assessment of Spondyloarthritis International Society (ASAS) did not include it in the recommended core measures for the assessment of AS due to the uncertainty in the selection of the measure. ${ }^{10}$ ASQoL does not include items such as walking and body image. ${ }^{11}$ Also, it is not compatible with the International Classification of Functioning, Disability, and Health published by the WHO. In addition, the questions in the ASQoL are answered as "yes/no" rather than detailed explanations. This might be insufficient, as it may omit some minor but significant changes in patients' conditions. On the other hand, the personalized format of the PGI-AS creates standardization problems in clinical applications.

Due to the aforementioned problems in the AS-specific QoL scales, ASAS indicated that their recommendations should be revised in light of new evidence for the assessment of QoL..$^{10,12,13}$ As body image, mobility and employment are inadequately assessed by existing measures and the impacts of these determinants on an individual's HRQoL in terms of physical, social and emotional well-being are significant, a new AS-specific QoL scale, known as the Evaluation of Ankylosing Spondylitis Quality of Life (EASi-QoL), was developed by Dr. Kristie L. Haywood and colleagues in $2010 .{ }^{14}$ Its validity, reliability and responsiveness have also been proven. ${ }^{10,14}$ EASi-QoL contains 20 items in four dimensions. These are physical function (1-6 items), disease activity (7-10 items), emotional well-being (11-15 items), and social participation (16-20 items). Each item is scored on a 5-point scale (0-4). The scores of four dimensions are calculated independently. Lower scores indicate better QoL. ${ }^{14}$ Evaluation of the items on the 5-point scale provides EASi-QoL to be useful in clinical practice and able to reflect any important changes in the health of an individual. ${ }^{10}$ EASi-QoL has proven acceptability, reliability and validity across a large representative sample in the United Kingdom and in some other clinical trials. ${ }^{14-16}$ Therefore, in this study, we aimed to translate the EASi-QoL into the Turkish language and test its validity and reliability.

\section{PATIENTS AND METHODS}

Before the study, permission for translation and validation of EASi-QoL into Turkish language was obtained from Dr. Kirstie L. Haywood, who developed EASi-QoL. The study protocol was approved by the Numune Training and Research Hospital Scientific Research Assessment Committee. The study was conducted in accordance with the principles of the Declaration of Helsinki.

\section{Translation procedure}

We based on the American Association of Orthopedic Surgeons (AAOS) guideline in the translation process of the questionnaire. ${ }^{17,18}$ Translation from English into Turkish was 
performed by three bilingual translators. One of the translators was a medical doctor, who was informed about the aim of the study and content of the scale; however, others were also aware of the aim of the process. As it is recommended in the AAOS, the target language was the native language of the translators. The translators translated the questions independently and then a common text was prepared as a synthesis of the independent translations. The text was retranslated into English by two professional translators one of whose native language was English and they were not aware of the topic. Therefore, a pre-final version which reflects the original scale best and which is the most comprehensible and compatible with Turkish culture was formed. Then, the Turkish form was checked by a Turkish philology teacher to check for spelling, grammatical errors and to correct diction. Initially, the pre-final version was presented to the clinicians dealing with AS. Their opinions about the questions were taken. They were asked to indicate the points which may cause confusion in daily practice. The clinicians remarked that the questions were convenient to evaluate the QoL of the patients with AS. Afterwards, the pretest stage was initiated. In this step, the scale was presented to 20 patients who were diagnosed with AS according to the modified New York criteria. ${ }^{19}$ The patients were asked to indicate the points they had difficulty to comprehend or the ones they were unfamiliar to. No negative feedbacks were given about the questions. Then, the test stage was initiated. The Turkish form of EASi-QoL were provided in Appendices.

\section{Patients and settings}

One hundred patients (74 males; 26 females; mean age $38.2 \pm 9.9$ years; range 21 to 63 years) diagnosed with AS according to the modified New York criteria and who applied to the Physical Medicine and Rehabilitation Clinic of Numune Training and Research Hospital between September 2013 and March 2014 were enrolled. Patients were assessed by using ASAS recommendations for core outcome domains for the assessment in AS. ${ }^{20} \mathrm{~A}$ written informed consent was obtained from each patient.

The demographic data such as age, sex, occupation, marital status and educational level were recorded. The disease duration, peripheral joint involvement, duration of morning stiffness, inflammatory back pain, family history and the medications were questioned. Erythrocyte sedimentation rate (ESR) and C-reactive protein (CRP) levels were measured. CRP was measured by nephelometry (N: 0.0-5.0 mg/L) and the ESR was measured by Westergren method.

The patients were asked to remark the night pain and total pain severity in the last week on $10 \mathrm{~cm}$ Visual Analog Scale (VAS). The global assessment of the patient and the physician were performed on VAS.

To determine the disease activity, the Bath Ankylosing Spondylitis Disease Activity Index $(\mathrm{BASDAI})^{21}$ and the Ankylosing Spondylitis Disease Activity Score (ASDAS) scales ${ }^{22,23}$ were used. BASDAI consists of six items assessing fatigue, spinal pain, joint pain/swelling, localized tender points, and duration and severity of morning stiffness. The patients answered these questions considering the last week. The BASDAI score was calculated by summing the mean score of last two questions with other scores and dividing this sum to five. ${ }^{21}$ ASDAS is a recently developed assessment method of disease activity which contains back pain (BASDAI item 2), global assessment of the patient, peripheral joint pain and swelling (BASDAI item 3), duration of morning stiffness (BASDAI item 6), and acute phase response (CRP or ESR) parameters. These parameters were placed on the formulation and the ASDAS score was calculated. ${ }^{22,23}$

Enthesitis was determined according to the Maastricht Ankylosing Spondylitis Enthesitis Score (MASES). ${ }^{24}$ A total of 13 points including bilateral first costochondral joints, bilateral seventh costochondral joints, bilateral anterior superior iliac spines, bilateral iliac crests, bilateral posterior superior iliac spines, L5 spinous process, and bilateral proximal insertion of Achilles tendons were evaluated.

Functional status was evaluated by using the BASFI. ${ }^{25}$ BASFI consists of eight questions regarding daily activities and two questions assessing the capability to cope with daily living. ${ }^{22}$ The patients were asked to indicate how much difficulty they experienced performing the defined actions on $10 \mathrm{~cm}$ VAS. The BASFI was obtained by calculating the mean of the scores. 
In order to assess the spinal mobility, the Bath Ankylosing Spondylitis Metrology Index (BASMI), ${ }^{26}$ which is suggested by the ASAS, was used. To calculate the BASMI, the tragus to wall distance, the Modified Schober, lateral spinal flexion, cervical rotation and intermalleolar distance were measured. The measurements were scored between 0 and 10 according to cut-off values. The BASMI was calculated by dividing the total score to five.

The ASQoL, 27 a specific scale for AS, was used in order to evaluate the QoL of the patients. The ASQoL has 18 items each of which is answered with either yes or no. The answer "yes" corresponds to 1 point. Higher scores indicate poor QoL.

\section{Statistical analysis}

All analyses were performed using IBM Statistical Package for the Social Sciences for Windows, version 21.0 (IBM Corp., Armonk, New York, USA). The quantitative data were stated as the mean \pm standard deviation or median (minimum-maximum), while qualitative data were stated as frequency (\%).

Feasibility was assessed by calculating the percentages of missing items and evaluating the floor and ceiling effects. If more than 15\% of the patients had the possible minimum or maximum scores, it was considered that there were floor and ceiling effects.
Reliability of EASi-QoL was assessed by internal consistency and test-retest reliability. More consistent results reveal a more reliable scale. An intra-class correlation coefficient (95\% confidence interval) was used for the reliability analysis of the Turkish EASi-QoL. Internal consistency was determined by calculating Cronbach's alpha coefficient. Minimum acceptable value for Cronbach's alpha coefficient was 0.7. Intra-class correlation coefficient score greater than 0.7 was accepted as satisfactory. ${ }^{28}$ Test-retest reliability was evaluated with the paired sample t-test for subcategories of EASi-QoL and Kendall's tau-b coefficient for individual questions.

To test the construct validity, "scale validity" method was used. For this purpose, EASi-QoL was compared with an AS-specific tool, ASQoL by Pearson correlation. EASi-QoL was compared with BASFI, which is used for determination of physical function and other clinical parameters associated with disease activity and functional status (BASDAI, ASDAS, BASMI, MASES, pain severity, global assessments of the patient and the physician). Furthermore, the correlation between EASi-QoL and laboratory parameters such as ESR and CRP, which are used in evaluation and follow-up of AS patients, was investigated. Statistical significant boundary was given as 0.05 .

Explanatory and confirmatory analyses were performed to assess the structural validity of EASi-QoL. Construct validity of four dimensions

Table 1. Demographical and clinical patient data

\begin{tabular}{lccc}
\hline & Mean \pm SD & Median & Min-Max \\
\hline Age (year) & $38.2 \pm 9.9$ & 37.5 & $21-63$ \\
Disease duration (months) & $115.9 \pm 91.5$ & 96 & $10-480.0$ \\
Erythrocyte sedimentation rate (mm/hr) & $13.8 \pm 13.3$ & 8 & $1-70$ \\
C-reactive protein (mg/L) & $13.0 \pm 15.1$ & 6.75 & $0.2-72$ \\
Pain (10-cm VAS) & $4.0 \pm 2.8$ & 3.5 & $0-10$ \\
Patient's global assessment (10-cm VAS) & $3.8 \pm 2.7$ & 3 & $0-10$ \\
Physician's global assessment (10-cm VAS) & $3.7 \pm 2.8$ & 3 & $0-10$ \\
Ankylosing Spondylitis Quality of Life & $7.2 \pm 6.0$ & 3 & $0-18$ \\
Bath Ankylosing Spondylitis Disease Activity Index & $3.0 \pm 2.0$ & 2.7 & $0-8.8$ \\
Bath Ankylosing Spondylitis Functional Index & $3.3 \pm 1.8$ & 1.4 & $0-8.8$ \\
Bath Ankylosing Spondylitis Metrology Index & $0.6 \pm 1.7$ & 2 & $0.4-7.8$ \\
Maastricht Ankylosing Spondylitis Enthesitis Score & $2.0 \pm 1.0$ & 0 & $0-13$ \\
ASDAS-erythrocyte sedimentation rate & $2.4 \pm 1.1$ & 1.85 & $0.4-4.7$ \\
ASDAS-C-reactive protein & $5.8 \pm 5.2$ & 2.2 & $0.1-5.6$ \\
EASi-QoL-physical function (0-24) & $6.8 \pm 4.2$ & 4 & $0-19$ \\
EASi-QoL-disease activity (0-16) & $7.2 \pm 5.5$ & 6 & $0-16$ \\
EASi-QoL-emotional well-being (0-20) & $7.0 \pm 5.4$ & 6.5 & $0-18$ \\
EASi-QoL-social participation (0-20) & & 7 & $0-20$ \\
SD: Standard deviation; Min: Minimum; Max: Maximum; VAS: Visual Analog Scale; ASDAS: Ankylosing Spondylitis Disease Activity Score, \\
EASi-QoL: Evaluation of Ankylosing Spondylitis Quality of Life. & & \\
\hline
\end{tabular}


Table 2. Test-retest results of Evaluation of Ankylosing Spondylitis Quality of Life

\begin{tabular}{lcccccc}
\hline & \multicolumn{2}{c}{ Test } & \multicolumn{2}{c}{ Re-test } & \\
\cline { 2 - 5 } & Median & IQR & & Median & IQR & $p$ \\
\hline Physical function & 4 & 8.75 & & 5 & 7.00 & $>0.05$ \\
Disease activity & 6 & 7.00 & 6 & 7.00 & $>0.05$ \\
Emotional well-being & 6.5 & 10.00 & & 7 & 10.00 & $>0.05$ \\
Social participation & 7 & 9.75 & 7 & 10.00 & $>0.05$ \\
\hline IQR: Interquartile range. & & & & & \\
\hline
\end{tabular}

of EASi-QoL, physical function, disease activity, emotional well-being and social participation, were determined by examining its factor structure. ${ }^{29,30}$ Confirmatory factor analysis (CFA) was conducted using IBM Statistical Package for the Social Sciences Amos 23 (IBM Corp., Armonk, New York, USA).

\section{RESULTS}

The female to male ratio in the study was $1: 3$ (0.35). Thirty-four patients (34\%) had graduated from elementary school, 49 (49\%) from high school, and 16 (16\%) from university.

Forty percent of the patients were smokers. When questioned about their exercise activities, $30 \%$ reported that they exercised regularly, $7 \%$ stated that they exercised occasionally, and $63 \%$ reported that they did not exercise at all. Thirty-seven patients were on nonsteroidal antiinflammatory drugs (NSAIDs), 31 were using both sulfasalazine and NSAIDs, and 31 patients were on biologics.

The mean disease duration ranged from 10 months to 40 years, with a mean of 115.9 \pm 91.6 months. Twenty-seven patients had a history of peripheral arthritis, and 34 patients had a first degree relative with AS. The mean duration of morning stiffness was $26.9 \pm 36.2$ minutes, and the median value of total pain severity (0-10 cm VAS) was 4.02 .

Scores of ASQoL, BASDAI, BASFI, BASMI, MASES, ASDAS, and EASi-QoL domains (physical function, disease activity, emotional wellbeing and social participation) and demographics and clinical data were summarized in Table 1.

Descriptive statistics of EASi-QoL scores, internal consistency and floor and ceiling effects were shown in Table 2. The internal consistency of EASi-QoL was determined with Cronbach's alpha coefficient, which was 0.910 in the physical function category, 0.893 in the disease activity category, 0.935 in the emotional well-being category, and 0.930 in the social contribution category $(\alpha>0.7)$.

Intra-class correlation coefficient value that was used for the reliability analysis of the Turkish EASi-QoL was 0.993. These values indicated the high reliability of our scale.

Explanatory factor analysis was performed to assess the structural validity of EASi-QoL. The results of the explanatory factor analysis indicated that the factor loadings were higher than 0.40 for all items. In addition to these, we evaluated all structures by using confirmative

Table 3. Relationships between first scores and second scores for each question in Evaluation of Ankylosing Spondylitis Quality of Life

\begin{tabular}{cccc}
\hline & \multicolumn{2}{c}{ Kendall's tau-b } & \\
\cline { 2 - 3 } & Value & Standard error & $p$ \\
\hline Question & & & \\
1 & 0.721 & 0.047 & $<0.001$ \\
2 & 0.754 & 0.045 & $<0.001$ \\
3 & 0.779 & 0.042 & $<0.001$ \\
4 & 0.751 & 0.040 & $<0.001$ \\
5 & 0.791 & 0.037 & $<0.001$ \\
6 & 0.882 & 0.034 & $<0.001$ \\
7 & 0.707 & 0.045 & $<0.001$ \\
8 & 0.861 & 0.025 & $<0.001$ \\
9 & 0.686 & 0.047 & $<0.001$ \\
10 & 0.755 & 0.048 & $<0.001$ \\
11 & 0.785 & 0.031 & $<0.001$ \\
12 & 0.721 & 0.034 & $<0.001$ \\
13 & 0.747 & 0.033 & $<0.001$ \\
14 & 0.732 & 0.039 & $<0.001$ \\
15 & 0.811 & 0.034 & $<0.001$ \\
16 & 0.787 & 0.037 & $<0.001$ \\
17 & 0.815 & 0.034 & $<0.001$ \\
18 & 0.820 & 0.042 & $<0.001$ \\
19 & 0.830 & 0.026 & $<0.001$ \\
20 & 0.788 & 0.032 & $<0.001$ \\
\hline $\mathrm{p}<0.001$ : Highly significant. & & \\
\hline
\end{tabular}


Table 4. Correlations of Evaluation of Ankylosing Spondylitis Quality of Life with other clinical parameters

\begin{tabular}{|c|c|c|c|c|c|c|c|c|}
\hline & \multicolumn{8}{|c|}{ Evaluation of Ankylosing Spondylitis Quality of Life } \\
\hline & \multicolumn{2}{|c|}{ Physical function } & \multicolumn{2}{|c|}{ Disease activity } & \multicolumn{2}{|c|}{ Emotional well-being } & \multicolumn{2}{|c|}{ Social participation } \\
\hline & $\mathrm{r}$ & $p$ & $\mathrm{r}$ & $p$ & r & $p$ & $\mathrm{r}$ & $p$ \\
\hline ASQoL & $0.799 * *$ & $<0.001$ & $0.722^{* *}$ & $<0.001$ & $0.806^{* *}$ & $<0.001$ & $0.891^{* * *}$ & $<0.001$ \\
\hline BASDAI & $0.713^{* *}$ & $<0.001$ & $0.753^{* *}$ & $<0.001$ & $0.717^{* *}$ & $<0.001$ & $0.707^{* * *}$ & $<0.001$ \\
\hline BASFI & $0.765^{* *}$ & $<0.001$ & $0.669^{* * *}$ & $<0.001$ & $0.671^{* *}$ & $<0.001$ & $0.740^{* * *}$ & $<0.001$ \\
\hline BASMI & $0.289^{*}$ & $<0.05$ & $0.255^{*}$ & $<0.05$ & $0.330^{*}$ & $<0.05$ & $0.300^{*}$ & $<0.05$ \\
\hline MASES & $0.269^{*}$ & $<0.05$ & $0.239^{*}$ & $<0.05$ & $0.370^{* *}$ & $<0.001$ & $0.340^{*}$ & $<0.05$ \\
\hline ASDAS-ESR & $0.631^{* * *}$ & $<0.001$ & $0.695^{* * *}$ & $<0.001$ & $0.621^{* * *}$ & $<0.001$ & $0.638^{* * *}$ & $<0.001$ \\
\hline ASDAS-CRP & $0.632^{* *}$ & $<0.001$ & $0.691^{* *}$ & $<0.001$ & $0.585^{* *}$ & $<0.001$ & $0.615^{* *}$ & $<0.001$ \\
\hline ESR & 0.184 & 0.068 & $0.201^{*}$ & $<0.05$ & 0.194 & 0.053 & 0.153 & 0.127 \\
\hline CRP & $0.210^{*}$ & $<0.05$ & $0.293^{*}$ & $<0.05$ & $0.226^{*}$ & $<0.05$ & $0.226^{*}$ & $<0.05$ \\
\hline Pain (10-cm VAS) & $0.642^{* *}$ & $<0.001$ & $0.735^{* * *}$ & $<0.001$ & $0.659^{* * *}$ & $<0.001$ & $0.714^{* *}$ & $<0.001$ \\
\hline Patient's global assessment & $0.650^{* *}$ & $<0.001$ & $0.720^{* *}$ & $<0.001$ & $0.639^{* *}$ & $<0.001$ & $0.684^{* * *}$ & $<0.001$ \\
\hline Physician's global assessment & $0.466^{* *}$ & $<0.001$ & $0.613^{* *}$ & $<0.001$ & $0.506^{* *}$ & $<0.001$ & $0.508^{* *}$ & $<0.001$ \\
\hline
\end{tabular}

factor analysis. Model fit statistics were analyzed, and the Comparative Fit Index (CFI) was 0.984, the Tucker-Lewis Index (TLI) was 0.995, and the root mean square error of approximation (RMSEA) was 0.098. CFI and TLI values higher than 0.95 indicated a good fit and RMSEA values close to 0.08 indicated an acceptable fit.

Confirmatory factor analysis is also a powerful statistical tool for assessing the construct validity of four dimensions of EASi-QoL. CFA shows the factor loadings of physical function, disease activity, emotional well-being, and social participation dimensions of EASi-QoL, which were acceptable for all items being higher than 0.7.

The relationships between the first scores and second scores (taken 72 hours later) for each question in EASi-QoL were given in Table 3. The lowest correlation value was 0.686 (question 9). High correlation values indicate strong relationships between the first and second scores $(p<0.001)$.

In order to test its structural validity, the correlations between EASi-QoL and pain severity, patient's global assessment, physician's global assessment, ASQoL, BASDAI, BASFI, BASMI, and MASES were analyzed. There was a strong positive correlation between all subcategories of EASi-QoL (physical function, disease activity, emotional well-being, and social participation) and ASQoL, BASDAI, BASFI, and pain severity.
There was a strong correlation between patient's global assessment and all subcategories of EASi-QoL, while there was a moderate degree of correlation between these subcategories and physician's global assessment. An investigation of the relationship between EASi-QoL and BASMI revealed a weak correlation in the physical function and disease activity categories and a moderate correlation in the emotional well-being and social participation categories.

Analysis of the correlation between EASi-QoL and MASES revealed a weak correlation in the physical function and disease activity categories and a moderate correlation in the emotional wellbeing and social participation categories.

We found a weak correlation between all subcategories with CRP level. In addition, there was a weak correlation between ESR and the disease activity subcategory of EASi-QoL. However, there were no other statistically significant correlations between other subcategories and ESR. All subcategories of EASi-QoL were strongly and positively correlated with ASDAS-ESR and ASDAS-CRP.

Physical function category of EASi-QoL showed the highest correlation with ASQoL. Besides, ASQoL showed the highest correlation with the emotional well-being and social participation categories. Parameter which showed the highest correlation with disease activity category was BASDAI. All these correlations demonstrated 
the structural validity of the Turkish version of EASi-QoL (Table 4).

\section{DISCUSSION}

Previous AS-specific QoL scales failed to adequately assess QoL in terms of body image, mobility and employment. Thus, we intended to translate EASi-QoL into our language because of its accuracy in demonstrating a patient's QoL in detail.

The EASi-QoL evaluates patients in four categories including physical function, disease activity, emotional well-being, and social contribution. With this method, patients respond the scale items using a 5-point scale (0-4), which allows patients to express themselves in detail, and enables the detection of both minor and significant changes in an individual's health. ${ }^{10,14}$

To our knowledge based on an extensive literature research, there has been no study prior to the current study in which a translated version of EASi-QoL was used. In the current study, we tested the reliability and the validity of the Turkish version of EASi-QoL.

Consistent with the recommendations in the AAOS guidelines, we prepared a Turkish version of the form with contributions from three translators. The translators agreed to use the Turkish word "etkileme" for the English word "interfere," rather than the exact Turkish phrase "engellemek, müdahale etmek." The word "etkileme" is used in questions 13, 16, 17, 18 and 19. Similarly, the phrase in question 8, which reads "interfere with your sleep," was translated as "uykunuzu ne kadar böldü." Following the translation, a reverse-translation to the source language was performed. Although a reverse-translation is not recommended by Swaine-Verdier, it was recommended in the AAOS guidelines, as it should increase the reliability of the scale. ${ }^{18}$ Therefore, in our study, the scale was translated back into English by two translators who were blinded to the original questions. The AAOS guidelines recommend that the reverse translation should be performed by translators whose native language is the source language. ${ }^{18}$ In our study, one of the translators was a native
English speaker, while the other was a native Turkish speaker. European Group for Health Measurement and QoL Assessment states that the native language of the translators who perform the reverse-translation can be the target language. ${ }^{18}$

After the reverse-translation, we took the following steps, which are recommended in various international translation guidelines: evaluation, pre-test, and test.

The scale was evaluated by a committee of physiatrists. The AAOS has recommended that the evaluation committee should include a methodologist, language experts, translators, and health professionals. ${ }^{18}$ Our committee included only health professionals. However, when we consulted the translation guidelines, the Functional Assessment of Cancer Therapy Group accepts that the evaluation committee can include only bilingual health professionals, ${ }^{18}$ and therefore, our team fulfilled these criteria. Question 2 included the phrase "1 mile walking". Since the metric system is used in our country, and 1 mile is equal to 1609 meters, we translated this statement as "walking 1.5 kilometers." A Turkish language and literature teacher checked the scale for grammatical errors.

After this evaluation, we performed the pre-test. This step is highly recommended to foresee any possible problems that will be faced by clinicians during the use of the scales. The Mapi Research Institute also recommends a parallelphase pre-test to be applied to both clinicians and patients, ${ }^{18}$ and therefore, this method was used during the pre-test phase of our study. Our scale was first given to clinical experts in the field of AS, and their feedback was collected. Later, we applied this scale to 20 patients who were diagnosed with AS according to the modified New York criteria. Number of subjects recommended in the literature to perform pretest version of scales ranges between 3 and $50 .{ }^{18}$ In our study, the pre-test version was performed on 20 AS patients. Both the clinicians and the patients reported that they easily comprehended the scale, which supported the validity of the Turkish version of EASi-QoL. ${ }^{28}$

When translation process of our study was analyzed, it was compatible with international guidelines. ${ }^{18}$ 
The ratio of males to females in our study was nearly 3:1, which is consistent with the literature, where it has been reported to be between 2:1 and 3:1. ${ }^{31}$ The prevalence of AS in first-degree relatives of AS patients has been reported to be $10-30 \%$ in the literature. In our study, $34 \%$ of the patients had a positive family history. Previous studies have shown that $20-40 \%$ of AS patients have peripheral joint involvement, and $27 \%$ of the patients in the current study had peripheral involvement. ${ }^{32}$

In order to be valid, a test must be reliable. Reliability indicates that the scale is repeatable and internally consistent. The test-retest and the parallel tests methods are recommended for determining reliability of stability. In the current study, we used the test-retest method to demonstrate reliability of stability. For the test-retest method, the patients were asked to fill in the scale twice within a 72-hour interval. Recommended intervals in the literature range from a few hours to six months. It is important that the interval is long enough so that the patients forget their previous response, but short enough so that there are no changes in the tested item. $^{28}$

In the current study, the test-retest reliability determined no significant difference when the test and re-test scores of the four subcategories were compared. The strong relationships between the first and second answers indicate that EASi-QoL provided a repeatable scale with compatible results at different times of application.

Internal consistency is another important parameter of reliability. The internal consistency of a scale describes the compatibility of its subcategories. The most commonly used statistical method for the determination of internal consistency is the Cronbach's alpha coefficient, of which values higher than 0.7 are accepted as significant. ${ }^{28}$ For EASi-QoL, the Cronbach's alpha coefficient was 0.910 in the physical function category, 0.893 in the disease activity category, 0.935 in the emotional well-being category, and 0.930 in the social contribution category. These values indicate that our scale has high reliability.

We used both explanatory and confirmatory factor analyses to determine the structural validity of EASi-QoL. High factor weights confirm the acceptable fit of the questionnaire.
The "scale validity" method was used to determine the structural validity of our study. We compared EASi-QoL and ASQoL, which is a reliable and valid scale for QoL evaluation in AS. There was a strong correlation between ASQoL and EASi-QoL subcategories. These results indicate that EASi-QoL has high structural validity.

Several studies have reported a relationship between disease activity and QoL. Bodur et al. ${ }^{33}$ reported a strong correlation between QoL in AS and disease activity. Zhao et al. ${ }^{34}$ also reported a relationship between QoL and disease activity. Haywood et al. ${ }^{14}$ reported a strong correlation between BASDAI and the four subcategories of EASi-QoL, including disease activity. In our current study, there was a positive correlation between BASDAI and all four subcategories of EASi-QoL, although the disease activity subcategory had the strongest correlation. These results support the structural validity of EASi-QoL and confirm the results of prior studies that indicate a relationship between disease activity and QoL.

Physical function is a parameter known to be closely related to QoL. In a study by Zhao et al., ${ }^{34}$ patients were grouped according to their disease activity, which was defined as mild, moderate, or severe. In all of the groups, QoL was assessed by ASQoL and correlated with BASFI. Their results indicated that physical function was a major factor affecting QoL, independent of disease activity level. Haywood et al. ${ }^{14}$ showed that the physical function subcategory of EASi-QoL had the highest correlation with BASFI. We confirmed this finding in our study, which also revealed a strong correlation between the physical function subcategory of EASi-QoL and BASFI. The strong correlation confirms the structural validity of Turkish version of EASi-QoL.

Loss of spinal mobility in AS negatively affects QoL. In a study by Bodur et al., 33 QoL in AS patients correlated well with the BASMI scale in AS patients, which is used to assess spinal mobility. Other studies have also reported a relationship between spinal mobility and QoL. 3,34,35 In this study, we also found a correlation between EASi-QoL and BASMI.

The VAS is an effective method that is used to assess pain and stiffness in AS. In our study, we used the VAS scale $(0-10 \mathrm{~cm})$ to assess patient and physician global evaluations as well as total pain 
severity, and found a relationship between total pain severity, patient global assessment, physician global assessment, and EASi-QoL. There are several other reports indicating a negative effect of pain severity on QoL in AS. ${ }^{3,27,33,34,36,37}$

It is widely accepted that acute phase reactants, ESR, and $\mathrm{CRP}$ do not reflect the clinical course entirely in AS. Normal values of these parameters do not eliminate the active disease. $^{38}$ In our study, there was a weak but statistically significant correlation between ESR and CRP values and the disease activity domain of EASi-QoL. Another method for assessing disease activity in AS is ASDAS, which was recently developed by ASAS. This is the first disease activity index that combines patient responses and acute phase reactants in AS. ${ }^{22,23}$ In the present study, we demonstrated a strong correlation between EASi-QoL and ASDAS-ESR and ASDAS-CRP scores.

In conclusion, our study demonstrated that EASi-QoL, which evaluates four major components of QoL (i.e., physical function, disease activity, emotional well-being, and social participation), was strongly correlated with ASQoL in patients with AS. The disease activity domain was correlated strongly with BASDAI, and the physical function domain with BASFI. Turkish version of EASi-QoL is a reliable and valid scale that can be used in clinical practice to evaluate the QoL in detail in AS patients.

\section{Declaration of conflicting interests}

The authors declared no conflicts of interest with respect to the authorship and/or publication of this article.

\section{Funding}

The authors received no financial support for the research and/or authorship of this article.

\section{REFERENCES}

1. Kotsis K, Voulgari PV, Drosos AA, Carvalho AF, Hyphantis T. Health-related quality of life in patients with ankylosing spondylitis: a comprehensive review. Expert Rev Pharmacoecon Outcomes Res 2014;14:857-72.

2. Sieper J, Braun J, Rudwaleit M, Boonen A, Zink A. Ankylosing spondylitis: an overview. Ann Rheum Dis 2002;61 Suppl 3:iii8-18.
3. Bostan EE, Borman P, Bodur H, Barça N. Functional disability and quality of life in patients with ankylosing spondylitis. Rheumatol Int 2003;23:121-6.

4. Doward LC, Spoorenberg A, Cook SA, Whalley D, Helliwell PS, Kay LJ, et al. Development of the ASQoL: a quality of life instrument specific to ankylosing spondylitis. Ann Rheum Dis 2003;62:20-6.

5. Study protocol for the World Health Organization project to develop a Quality of Life assessment instrument (WHOQOL). Qual Life Res 1993;2:153-9.

6. Testa MA, Simonson DC. Assessment of quality-of-life outcomes. N Engl J Med 1996;334:835-40.

7. Ward MM. Quality of life in patients with ankylosing spondylitis. Rheum Dis Clin North Am 1998;24:815-27

8. Fortin M, Dubois MF, Hudon C, Soubhi H, Almirall J. Multimorbidity and quality of life: a closer look. Health Qual Life Outcomes 2007;5:52.

9. Haywood KL, Garratt AM, Dziedzic K, Dawes PT. Patient centered assessment of ankylosing spondylitisspecific health related quality of life: evaluation of the Patient Generated Index. J Rheumatol 2003;30:764-73.

10. Packham JC, Jordan KP, Haywood KL, Garratt AM, Healey EL. Evaluation of Ankylosing Spondylitis Quality of Life questionnaire: responsiveness of a new patient-reported outcome measure. Rheumatology (Oxford) 2012;51:707-14.

11. Zochling J, Braun J, van der Heijde D. Assessments in ankylosing spondylitis. Best Pract Res Clin Rheumatol 2006;20:521-37.

12. van der Heijde D, Bellamy N, Calin A, Dougados M, Khan MA, van der Linden S. Preliminary core sets for endpoints in ankylosing spondylitis. Assessments in Ankylosing Spondylitis Working Group. J Rheumatol 1997;24:2225-9.

13. van der Heijde D, Calin A, Dougados M, Khan MA, van der Linden S, Bellamy N. Selection of instruments in the core set for DC-ART, SMARD, physical therapy, and clinical record keeping in ankylosing spondylitis. Progress report of the ASAS Working Group. Assessments in Ankylosing Spondylitis. J Rheumatol 1999;26:951-4.

14. Haywood KL, Garratt AM, Jordan KP, Healey EL, Packham JC. Evaluation of ankylosing spondylitis quality of life (EASi-QoL): reliability and validity of a new patient-reported outcome measure. J Rheumatol 2010;37:2100-9.

15. Sandhu J, Packham JC, Healey EL, Jordan KP, Garratt AM, Haywood KL. Evaluation of a modified arthritis self-efficacy scale for an ankylosing spondylitis UK population. Clin Exp Rheumatol 2011;29:223-30.

16. Mattey DL, Dawson SR, Healey EL, Packham JC. Relationship between smoking and patient-reported measures of disease outcome in ankylosing spondylitis. J Rheumatol 2011;38:2608-15.

17. Guillemin F, Bombardier C, Beaton D. Cross-cultural adaptation of health-related quality of life measures: literature review and proposed guidelines. J Clin Epidemiol 1993;46:1417-32. 
18. Acquadro C, Conway K, Hareendran A, Aaronson N. Literature review of methods to translate health-related quality of life questionnaires for use in multinational clinical trials. Value Health 2008;11:509-21.

19. van der Linden S, Valkenburg HA, Cats A. Evaluation of diagnostic criteria for ankylosing spondylitis. A proposal for modification of the New York criteria. Arthritis Rheum 1984;27:361-8.

20. Sieper J, Rudwaleit M, Baraliakos X, Brandt J, Braun J, Burgos-Vargas R, et al. The Assessment of SpondyloArthritis international Society (ASAS) handbook: a guide to assess spondyloarthritis. Ann Rheum Dis 2009;68 Suppl 2:ii1-44.

21. Akkoc Y, Karatepe AG, Akar S, Kirazli Y, Akkoc N. A Turkish version of the Bath Ankylosing Spondylitis Disease Activity Index: reliability and validity. Rheumatol Int 2005;25:280-4.

22. Lukas C, Landewé R, Sieper J, Dougados M, Davis $\mathrm{J}$, Braun J, et al. Development of an ASAS-endorsed disease activity score (ASDAS) in patients with ankylosing spondylitis. Ann Rheum Dis 2009;68:18-24.

23. van der Heijde D, Lie E, Kvien TK, Sieper J, Van den Bosch F, Listing $\mathrm{J}$, et al. ASDAS, a highly discriminatory ASAS-endorsed disease activity score in patients with ankylosing spondylitis. Ann Rheum Dis 2009;68:1811-8.

24. Heuft-Dorenbosch L, Spoorenberg A, van Tubergen A, Landewé $\mathrm{R}$, van ver Tempel $\mathrm{H}$, Mielants $\mathrm{H}$, et al. Assessment of enthesitis in ankylosing spondylitis. Ann Rheum Dis 2003;62:127-32.

25. Yanik B, Gürsel YK, Kutlay S, Ay S, Elhan AH. Adaptation of the Bath Ankylosing Spondylitis Functional Index to the Turkish population, its reliability and validity: functional assessment in AS. Clin Rheumatol 2005;24:41-7.

26. Jenkinson TR, Mallorie PA, Whitelock HC, Kennedy LG, Garrett SL, Calin A. Defining spinal mobility in ankylosing spondylitis (AS). The Bath AS Metrology Index. J Rheumatol 1994;21:1694-8.

27. Duruöz MT, Doward L, Turan Y, Cerrahoglu L, Yurtkuran M, Calis M, et al. Translation and validation of the Turkish version of the Ankylosing Spondylitis Quality of Life (ASQOL) questionnaire. Rheumatol Int 2013;33:2717-22.

28. DeVon HA, Block ME, Moyle-Wright P, Ernst DM,
Hayden SJ, Lazzara DJ, et al. A psychometric toolbox for testing validity and reliability. $J$ Nurs Scholarsh 2007;39:155-64.

29. Jackson DL, Gillaspy JA, Purc-Stephenson R. Reporting practices in confirmatory factor analysis: an overview and some recommendations. Psychol Methods 2009;14:6-23.

30. Schreiber JB, Nora A, Stage FK, Barlow EA, King J. Reporting structural equation modeling and confirmatory factor analysis results: a review. The Journal of Educational Research 2006;99:323-37.

31. Rudwaleit M. Classification and epidemiology of spondyloarthritis. In: Hochberg MC editor. Rheumatology. 5th ed, Philadelphia: Mosby Elsevier; 2011. p. 1123-8.

32. Gensler L. Clinical features of ankylosing spondylitis. In: Hochberg MC editor. Rheumatology. 5th ed. Philadelphia: Mosby Elsevier; 2011. p. 1129-34.

33. Bodur H, Ataman S, Rezvani A, Buğdaycı DS, Cevik $\mathrm{R}$, Birtane $\mathrm{M}$, et al. Quality of life and related variables in patients with ankylosing spondylitis. Qual Life Res 2011;20:543-9.

34. Zhao LK, Liao ZT, Li CH, Li TW, Wu J, Lin Q, et al. Evaluation of quality of life using ASQoL questionnaire in patients with ankylosing spondylitis in a Chinese population. Rheumatol Int 2007;27:605-11.

35. Ibn Yacoub Y, Amine B, Laatiris A, Abouqal R, HajjajHassouni N. Health-related quality of life in Moroccan patients with ankylosing spondylitis. Clin Rheumatol 2011;30:673-7.

36. Yllmaz O, Tutoğlu A, Garip Y, Ozcan E, Bodur $\mathrm{H}$. Health-related quality of life in Turkish patients with ankylosing spondylitis: impact of peripheral involvement on quality of life in terms of disease activity, functional status, severity of pain, and social and emotional functioning. Rheumatol Int 2013;33:1159-63.

37. Jenks K, Treharne GJ, Garcia J, Stebbings S. The ankylosing spondylitis quality of life questionnaire: validation in a New Zealand cohort. Int $\mathrm{J}$ Rheum Dis 2010;13:361-6.

38. Ruof J, Stucki G. Validity aspects of erythrocyte sedimentation rate and C-reactive protein in ankylosing spondylitis: a literature review. J Rheumatol 1999;26:966-70. 


\section{APPENDICES}

\section{EK-2: EASi-QoL'un TÜRKÇE VERSIYONU}

\section{EASi-QoL}

(Ankilozan Spondilit Yaşam kalitesi Değerlendirme Ölçeği)

\section{ANKILOZAN SPONDILITE BAĞLI KISITLILIKLAR}

Aşağıdaki sorular Ankilozan Spondilit hastalığınızın sizde sebep olduğu problemleri sorgular. Lütfen her soruyu bir çarpı ile işaretleyiniz. Eger soruya nasıl cevap vereceğinizden emin değilseniz lütfen en uygun cevabı veriniz.

Bu sorular bir gün içerisinde yapabileceğiniz aktiviteler ile ilgilidir. Ankilozan Spondilit hastalığınız sizi bugün bu aktiviteleri yaparken kısıtlıyor mu? Eğer kısıtladıysa ne kadar?

Her soru için lütfen sizin için uygun olan bir seçeneği çarpı ile işaretleyiniz.

Lütfen her satırda yalnızca bir kutucuğu çarpı koyarak işaretleyiniz.

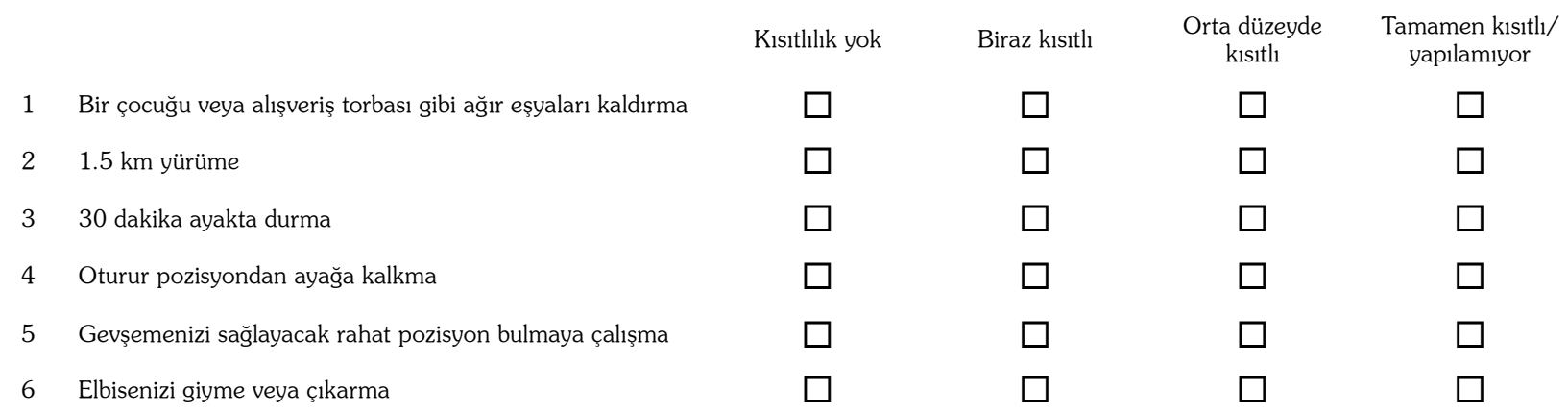

Şimdi size geçtiğimiz hafta ile ilgili sorular sormak istiyoruz. Ankilozan Spondilitin günlük değişkenlikler gösterdiğini anlıyoruz, ancak sorulara gectiğimiz hafta boyunca ortalama olarak kendinizi nasıl hissettiğinize göre cevap vermenizi istiyoruz.

Lütfen her soruyu bir çarpı işareti ile cevaplayınız. Eğer nasıl cevap vereceğinizden emin değilseniz lütfen en uygun cevabı veriniz.

Hiç Çok az Şrok fazla

$7 \quad$ Geçtiğimiz hafta Ankilozan Spondilit hastalığnız sizde ne kadar ağrı veya rahatsızlığa neden oldu?

$8 \quad$ Geçtiğimiz hafta hastalı̆ı̆ıı uykunuzu ne kadar böldü?

Hiçbir zaman Çok nadir $\quad$ Orta derecede Şo sık fazla

9 Geçtiğimiz hafta Ankilozan Spondilit hastalığııız nedeniyle ne kadar süreyle kendinizi yorgun veya enerjisini yitirmiş hissettiniz?

Hiç Çok az Orta derecede Şok fazla

10 Geçtiğimiz hafta Ankilozan Spondilit hastalığınız ne kadar sabah tutukluguna sebep oldu? 
Hiçbir zaman $\quad$ Çok nadir $\quad$ Bazen $\quad$ Çoğu zaman Her zaman

12 Geçtiğimiz hafta Ankilozan Spondilit hastalığınız ne kadar süreyle gelecekle ilgili (iș, başka kişilerle ilgilenebilme, sosyal yaşam ve aktif kalma gibi) kaygı duymanıza sebep oldu?

Hiç

Çok az

Orta derecede

Sik sik

Çok fazla

13 Geçtiğimiz hafta Ankilozan Spondilit hastalığınız sebebiyle ne kadar süreyle konsantrasyon yeteneğiniz (okuma, konuşan birini dinleme veya TV seyretme) etkilendi?

14 Geçtiğimiz hafta Ankilozan Spondilit hastalığınız sebebiyle ne kadar süreyle isteksizlik veya motivasyon eksikliğiniz oldu?

Lütfen her soruya bir çarpı işareti ile cevap veriniz. Eğer nasıl cevap vereceğinizden emin değilseniz lütfen en uygun cevabı veriniz. hastalığınız sebebiyle kendinizi ne kadar süreyle üzgün hissettiniz?

16 Geçtiğimiz hafta Ankilozan Spondilit hastalığınız normal işlerinizi (ev ve ev dişı) ne kadar süreyle etkiledi?

Hiç zaman

$\square$

Hiç

Çok az

Geçtiğimiz hafta Ankilozan Spondilit

hastalığınız aile ve arkadaşlık

ilişkilerinizi ne kadar etkiledi?

18 Geçtiğimiz hafta Ankilozan Spondilit hastalığınız arabayla ya da toplu taşıma araçlarıyla (otobüs ve tren gibi) seyahat etmenizi ne kadar etkiledi?

19 Geçtiğimiz hafta Ankilozan Spondilit hastalı̆ı̆ınız fiziksel olarak aktif olabilmenizi ne kadar etkiledi?
20 Geçtiğimiz hafta Ankilozan Spondilitin yaşam kalitenizi etkilediğini kadar süreyle hissettiniz? 